\section{Suicide rates in the State of Rio Grande do Sul, Brazil: association with socioeconomic, cultural, and agricultural factors}

\author{
Taxas de suicídio no Estado do Rio Grande do Sul, \\ Brasil: associação com fatores sócio-econômicos, \\ culturais e agrários
}

\author{
1 Programa de Pós-graduação \\ em Epidemiologia, \\ Universidade Federal de \\ Pelotas, Pelotas, Brasil. \\ 2 Faculdade de Medicina \\ Universidade Federal de \\ Pelotas, Pelotas, Brasil. \\ 3 Programa de Pós-graduação \\ de Saúde Coletiva, \\ Universidade do Vale do Rio \\ dos Sinos, São Leopoldo, \\ Brasil. \\ ${ }^{4}$ Núcleo de Estudos de \\ Saúde Coletiva, \\ Universidade Federal do \\ Rio de Janeiro, \\ Rio de Janeiro, Brasil. \\ ${ }^{5}$ Faculdade de Medicina, \\ Universidade Federal do \\ Rio Grande do Sul, \\ Porto Alegre, Brasil. \\ Correspondence \\ N. M. X. Faria \\ Programa de Pós-graduação \\ em Epidemiologia, \\ Universidade Federal \\ de Pelotas. \\ Rua República 80, apto. 1401 \\ Bento Gonçalves, RS \\ 95700-000, Brasil. \\ neicef@italnet.com.br
}

\begin{abstract}
Rio Grande do Sul State has the highest suicide rates in Brazil. Previous studies have suggested a possible role of agricultural activities, especially tobacco farming, where pesticide use is intensive. An ecological study was designed to assess associations between age-adjusted suicide rates based on death certificates and socioeconomic and agricultural factors. Suicide rates in males and females were inversely associated with schooling level and directly associated with divorce/marital separation. Rates for men were higher in areas where traditional Protestant religious were more prevalent, and rates for women were lower in areas with a higher proportion of single-inhabitant households. Multivariate analyses showed no associations between increased suicide rates and any of the agricultural variables. These results confirm the role of socioeconomic determinants of suicide, but do not support the hypothesis of a specific role of agricultural practices.
\end{abstract}

Mortality Rate; Rural Population; Religion; Educational Status; Suicide
Neice Müller Xavier Faria 1 Cesar Gomes Victora 1,2 Stela Nazareth Meneghel 3 Lenine Alves de Carvalho 4 João Werner Falk 5

\section{Introduction}

In 1897, Durkheim demonstrated that suicide was related to social factors 1 . Since then various authors have sought to deepen the understanding of this phenomenon and identify economic, social, and cultural factors related to variations in its occurrence 2,3,4,5,6.

According to the World Health Organization (WHO), suicide is one of the three main causes of death among individuals from 15 to 35 years of age 7 . In 1999, deaths from suicide represented $17 \%$ of the deaths from external causes worldwide 8. In Brazil, in 2000, suicides accounted for $6 \%$ of deaths from external causes, while the proportion was $13 \%$ in the South of Brazil and $16 \%$ in the State of Rio Grande do Sul (DATASUS. Estatísticas Vitais - Mortalidade e Nascidos Vivos. http: / tabnet.datasus.gov.br/tabnet/tabnet.htm, accessed on $20 / J u l / 2004)$. In 1995, the Rio Grande do Sul State Health Department identified suicide as a serious public health problem, with an upward trend in various municipalities (counties) ${ }^{9}$.

In a publication prior to the current study, standardized suicide rates were calculated for 1980 to 1999, showing that the State had the highest rates in Brazil throughout this period. Suicide rates were higher in men, the elderly, widows/ widowers, and workers in the primary sector (farming, cattle-raising, and fishing) 10 .

The relationship between suicide and farming activities had already been suggested by pre- 
vious studies in Rio Grande do Sul. In 1992, an anthropological study identified high suicide rates in the State and their concentration in rural areas ${ }^{11}$. In 1995, a survey of deaths from suicide in the Municipality of Venâncio Aires, based on mortality data from the National Health System's Department of Data and Information Technology (DATASUS) and police records, suggested a possible association with tobacco farming, specifically involving the use of pesticides, a hypothesis that received widespread media coverage 12 . Later, analyzing the suicide rates in the various municipalities of Rio Grande do Sul, a sociological study reinforced the association between suicide and farming 13 .

Recognizing suicide as a public health problem, the current study aimed to identify factors associated with the high suicide rates in Rio Grande do Sul, including factors linked to farm production.

\section{Methods}

The study used an ecological design. To avoid problems related to emancipation of municipalities and to reduce annual fluctuations in rates (particularly important in smaller municipalities), the analytical units were defined as the State's 35 homogeneous geographic microregions, as defined by the Instituto Brasileiro de Geografia e Estatística (Brazilian Census Bureau - IBGE).

Data on the number of suicides were obtained from deaths reported to the Ministry of Health's Mortality Information (SIM), processed by DATASUS and available in CD-ROM using the Tabwin software 14 .

Deaths were identified by micro-region of residence, selecting the following codes from the International Classification of Diseases (ICD): ICD9 codes E950 to E959 (1994 and 1995) and ICD10 codes X60 to X84 and Y87 (1996 to 1998).

To avoid annual fluctuations, for each homogenous geographic micro-region the mean coefficients were calculated for the five-year period 1994 to 1998, using mean population as the denominator. All rates were expressed per 100 thousand persons 15 years or older. The study's initial objective was to examine associations between agricultural occupational factors and suicide rates, in addition to considering sociocultural factors like marriage and divorce, which also mainly affect adults. Suicides in individuals under 15 years of age represented fewer than $2 \%$ of the total, while this age group represented $29 \%$ of the total population during the same period 14 . Thus, these suicides were not included in the analysis, in order to exclude a population segment in which the incidence of the outcome and exposure to risk factors were low, which would have decreased the study's statistical power. The crude coefficients were standardized by age, using the WHO standard population 15 .

The selection of socioeconomic and cultural indicators to include in the analysis considered the available literature on suicide. The criteria for selecting target agricultural variables were their economic importance in the State and the intensity of pesticide use in the various crops, based on the opinions of agronomists and farm extension experts.

The sources for independent variables included the 1991 National Census and the 1996 Agricultural Census, both conducted by IBGE, the Anuário Estatístico [Statistical Yearbook] of the Rio Grande do Sul State Foundation for Economics and Statistics (FEE-RS), the Instituto Nacional de Colonização e Reforma Agrária (INCRA), and the Human Development Atlas, Brazil (United Nations Development Program - UNDP/Instituto de Pesquisa Econômica Aplicada - IPEA/Fundação João Pinheiro). The following data were collected, by micro-region:

- Per capita Gross Domestic Product (GDP) (added value from the production of all goods and services): mean value, 1996-1998 (source: FEE-RS);

- Percentage of heads of households with income greater than five times the prevailing minimum wage (1991);

- Expanded Municipal Social Index (ISMA): values pertaining to 1996 (source: FEE-RS). The ISMA is a composite indicator developed by FEERS to evaluate trends in social conditions in the State's municipalities. The index is based on 14 indicators organized in four groups: (i) housing and sanitation conditions, (ii) education, (iii) health; and (iv) income. The index varies from zero to one, and better results are those closest to one; - GINI income index: values pertaining to 1991 (source: IBGE). A measure of income concentration, varying from zero (maximum equality of income distribution) to one (maximum income concentration);

- Human Development Index (HDI): HDI-general, HDI-education, HDI-longevity, and HDIincome. Figures for 1991;

- Percentage of individuals with fewer than eight complete years of schooling in the population 15 years of age and older: figures for 1996 (source: IBGE);

- Demographic density: figures for 1998 (source: IBGE);

- GINI land index (rural property size): figures for 1998 (source: INCRA). Measure of land con- 
centration calculated analogously to the GINI income index, obtained through special tabulations of the INCRA database and statistical registry;

- Population urbanization rate: figures for 1996 (source: IBGE);

- Percentage of rural property measuring 100 hectares or more: figures for 1996 (source: IBGE); - Percentage of women in the rural workforce: figures for 1996 (source: IBGE);

- Fertility rate: figures for 1991 (source: PNUD);

- Dissolved marriages rates (divorces plus legal separations divided by the population 15 years of age and older, multiplied by 1,000): figures for 1995 (source: FEE);

- Population percentage by religion (Catholic, traditional Protestant, Pentecostal Protestant, African-Brazilian or umbanda/ candomblé, Spiritist, no religion, other): figures for 1991 (source: IBGE);

- Percentage of single-resident households: figures for 1991 (source: IBGE).

In addition to the above factors, data were collected on the main farm crops in Rio Grande do Sul, obtained from the 1996 Censo Agropecuário [Agricultural Census] (area in hectares divided by the total area of the micro-region multiplied by 1,000): tobacco, rice, soybeans, wheat, corn, beans, apples, grapes, peaches, pears, bananas, tomatoes, potatoes, onions, manioc, matte tea. Initial analysis of the religions focused on those practiced by at least $3 \%$ of the State population in 1991: Catholic, traditional Protestant, and Pentecostal. After evaluation of the crude correlation with dummy variables represented by each religious group, the variable selected for multivariate analysis was that with the strongest association with the outcome, namely the proportion of individuals belonging to traditional Protestant denominations.

One of the study's initial objectives was to investigate the hypothesis that pesticide use was associated with the increase in suicide rates. After an exhaustive search of official data on sale and consumption of pesticides, the only source identified was the Receituário Agronômico [Agronomical Prescription Registry], reporting of which is mandatory to the CREA-RS (Conselho Regional de Engenharia, Arquitetura e Agronomia, Rio Grande do Sul). CREA-RS had begun keying in the pesticide prescriptions and made the data available for the year 1996. However, evaluation of the 217 thousand prescriptions filled out that year showed that some two-thirds of the information on the amount of pesticides prescribed was missing, making reliable estimates impossible. Another potential source of information was the National Toxicological and Pharmacological
Data System (SINITOX). However, this system had been presented a important underreporting 16 , in addition to the fact that a major portion of the cases reported involved suicides or suicide attempts by ingestion of pesticides, i.e., where exposure was intentional rather than occupational 17 . Thus, it was not possible to use intensity of pesticide use as a variable in the analyses.

The data from the various sources were processed using the Tabwin and Excel programs. SPSS for Windows-10 (SPSS Inc., Chicago, USA) was used to organize the database and for the statistical analysis.

In the 20-year historical series, the male suicide rates showed an upward trend and were considerably higher than the female rates 10 , so all of the analyses were stratified by gender.

The explanatory variables were described in terms of means and standard deviations (SD) for the 35 micro-regions. Pearson correlations coefficients were calculated to evaluate associations between these factors and the standardized suicide rates. After this exploratory analysis, the indicators were selected to be included in the multiple linear regression model 18. For each set of related variables, the indicator with the best statistical performance was selected to be included in the regression model; for example, among the variables related to schooling (mean schooling in years, percentage of individuals with eight or more years of schooling, percentage without schooling, etc.), the variable "percentage of individuals with eight or more years of schooling" was chosen.

The multivariate analysis used a hierarchical model, based on a conceptual model stipulating two levels of causality, in addition to the outcome. The first level included socioeconomic, agricultural, and geographic factors. The second level focused on the main farm crops, adjusted for the first-level variables that remained in the model.

For each level of regression, the criterion for remaining in the equation was associations with $\mathrm{p}<0.20$.

\section{Results}

From 1994 to 1998 , there were 4,766 suicides among individuals 15 years or older in the State, including 3,804 men and 962 women. The mean number of suicides per year in the State was 953, or 761 men and 192 women, i.e., a male-female ratio of $4: 1$.

For both genders, the mean crude suicide coefficient in the 35 homogeneous geographic micro-regions was 15.2 ( $\mathrm{SD}=3.6$ ), and the stan- 
Figure 1

Standardized suicide rates by geographic micro-region. Rio Grande do Sul State, Brazil (grouped in quartiles).

\section{a) Suicide in men}

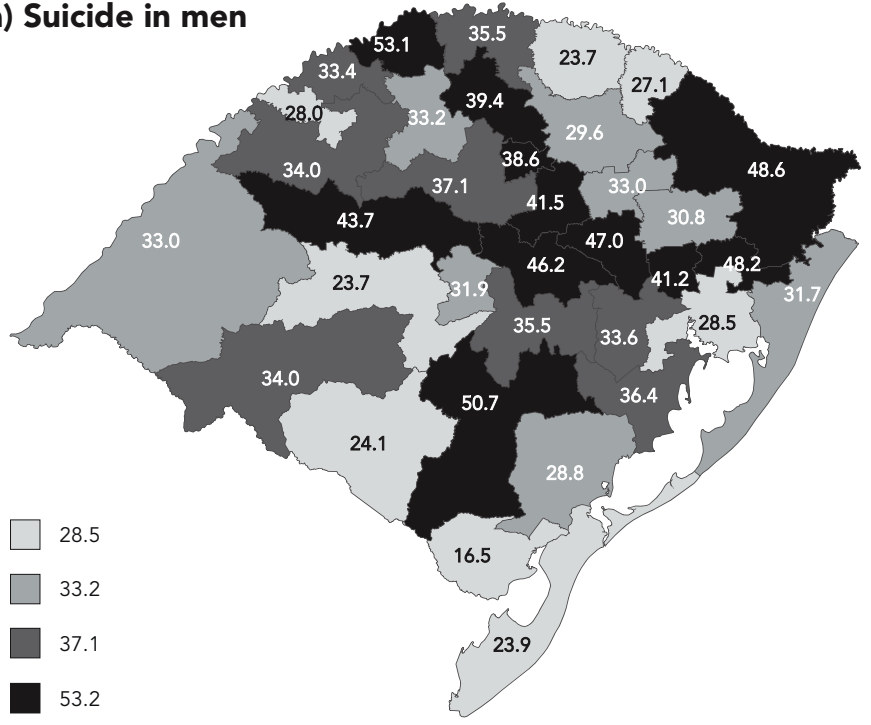

\section{b) Suicide in women}

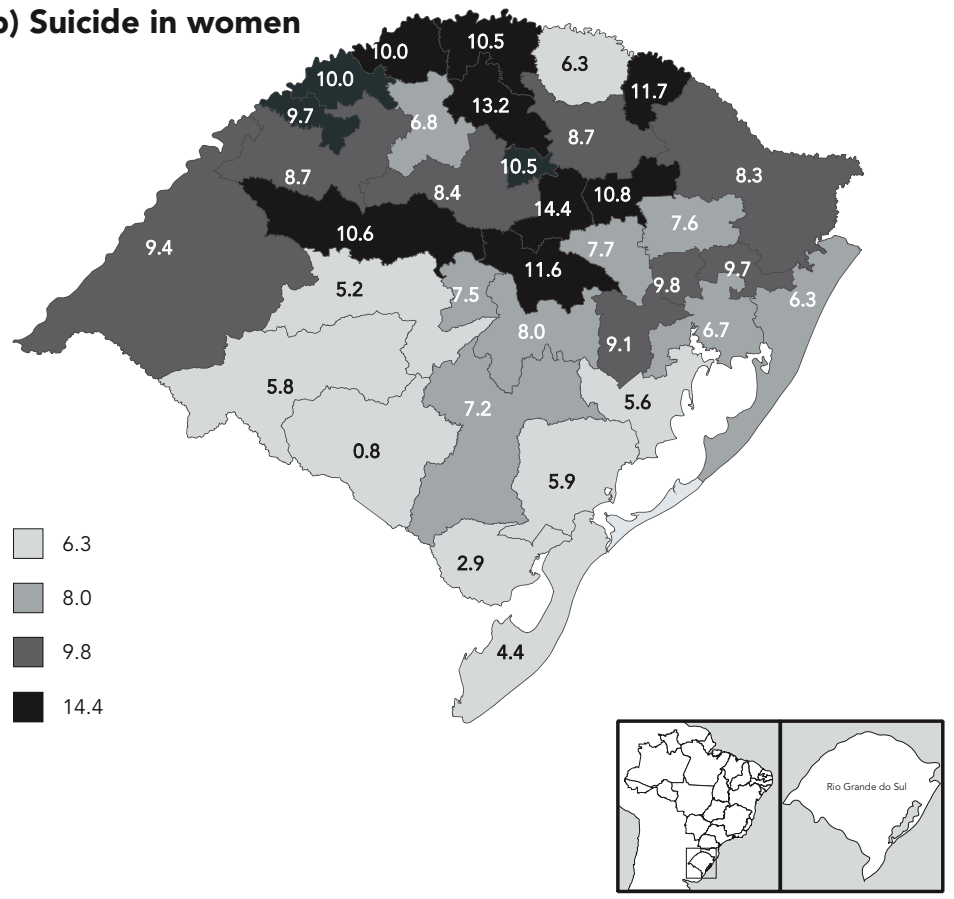

dardized coefficient was $20.9(\mathrm{SD}=5.2)$. The respective coefficients for men were 24.6 ( $\mathrm{SD}=5.9$ ) and $35.0(\mathrm{SD}=8.6)$ and for women $6.0(\mathrm{SD}=2.1)$ and $8.3(\mathrm{SD}=2.8)$. All coefficients were expressed per 100 thousand inhabitants 15 years or older.

Considering the standardized suicide rates for both gender, the micro-regions in the upper quartile were Três Passos (30.9), Santa Cruz (28.9), Vacaria (28.6), Gramado-Canela (28.0), Serras do Sudeste (28.0), Soledade (27.4), Santiago (26.4), Lajeado-Estrela (25.9), and Montenegro (25.1). Figure 1 shows the map with the suicide distribution by quartiles according to gender in the State's micro-regions.

The most common method was hanging ( $60.6 \%$ of suicides), followed by firearms (27.5\%). Workers in farming and fishing showed an even higher proportion of hangings: $75 \%$.

Table 1 shows the mean frequencies and ranges of the principal independent variables for the 35 micro-regions.

After evaluating the crude correlations between the explanatory variables and the standardized suicide rates, the following variables were selected for inclusion in the first level of the regression model: percentage of heads of households with income $>$ five times the minimum wage (upper income), percentage of persons with $\geq 8$ complete years of schooling in the population $\geq 15$ years of age (schooling), HDI-income, percentage of rural properties $\geq 100$ hectares (large land holdings), percentage of women in the rural workforce (female rural work), population urbanization rate (urbanization), dissolved marriages rates (dissolved marriages), and percentage of single-resident households (singleresident household).

Table 2 shows the correlations between the selected indicators as well as the main farm crops and standardized male and female suicide rates. The socioeconomic indicators (upper income, schooling, HDI-income), urbanization rate, large land-holdings, and single-residents households showed an inverse correlation with suicide, especially in women. Meanwhile, female rural work was correlated with increased suicide rates. Traditional Protestant religion showed a positive correlation with male suicide. Evaluating the relations between the main farm crops and suicide rates, there was an association between soybeans, wheat, and corn and increased female suicide rates. Meanwhile, rice farming was correlated with lower suicide rates in both men and women.

Table 3 shows the correlation matrix between explanatory variables. Schooling was higher in micro-regions with higher income, higher HDI, greater urbanization, higher disolved marriages 
Mean socioeconomic and cultural variables per micro-region.

\begin{tabular}{|c|c|c|c|}
\hline Independent variables & Year & Mean (SD) & Range \\
\hline \multicolumn{4}{|l|}{ Socioeconomic and cultural } \\
\hline Heads of households with income $>5$ minimum wage (\%) & 1991 & $12.9(4.1)$ & $7.5 ; 25.5$ \\
\hline Human Development Index (HDI-Income) & 1991 & $0.62(0.41)$ & $0.55 ; 0.71$ \\
\hline Schooling $\geq 8$ years [Population $\geq 15$ years of age] (\%) & 1996 & $31.3(5.6)$ & $21.7 ; 46.3$ \\
\hline Rural properties $\geq 100 h a(\%)$ & 1996 & $50.6(29.6)$ & $9.1 ; 94.1$ \\
\hline$\%$ Urban population/ total population & 1996 & $67.1(15.4)$ & $38.8 ; 95.2$ \\
\hline$\%$ Women in rural workforce & 1996 & $36.4(5.4)$ & $23.3 ; 42.9$ \\
\hline \% Single-resident households & 1991 & $7.4(1.9)$ & $4.2 ; 12.7$ \\
\hline Divorce rate * & 1995 & $1.8(0.6)$ & $0.06 ; 3.2$ \\
\hline$\%$ Catholic & 1991 & $82.8(8.7)$ & $57.6 ; 98.6$ \\
\hline$\%$ Protestant (total) & 1991 & $11.7(7.5)$ & $0.9 ; 29.7$ \\
\hline$\%$ Traditional Protestant & 1991 & $8.1(7.1)$ & $0.1 ; 22.4$ \\
\hline$\%$ Pentecostal Protestant & 1991 & $3.6(2.0)$ & $0.8 ; 9.1$ \\
\hline \multicolumn{4}{|l|}{ Farm crops (area cultivated/total area in $1,000 \mathrm{ha}$ ) } \\
\hline Tobacco & 1996 & $8.6(19.2)$ & $0.0 ; 106.5$ \\
\hline Rice & 1996 & $34.7(47.8)$ & $0.26 ; 167.9$ \\
\hline Soybeans & 1996 & $155.7(206.1)$ & $0.01 ; 607.1$ \\
\hline Wheat & 1996 & $37.8(53.7)$ & $0.0 ; 183.9$ \\
\hline Corn & 1996 & $95.4(82.1)$ & $4.4 ; 250.5$ \\
\hline Beans & 1996 & $11.9(20.2)$ & $0.02 ; 105.5$ \\
\hline Onions & 1996 & $0.9(2.0)$ & $0.01 ; 10.0$ \\
\hline Potatoes & 1996 & $2.7(5.8)$ & $0.01 ; 30.5$ \\
\hline Tomatoes & 1996 & $0.3(0.4)$ & $0.01 ; 1.9$ \\
\hline Apples & 1996 & $0.3(1.1)$ & $0.0 ; 4.8$ \\
\hline Grape & 1996 & $2.8(11.9)$ & $0.0 ; 70.7$ \\
\hline Peaches & 1996 & $0.6(1.3)$ & $0.01 ; 6.2$ \\
\hline
\end{tabular}

* Number of divorced + legally separated)/population $\geq 15$ years $\times 1,000$.

rates, and lower proportion of female rural work. The proportion of Protestants was higher in micro-regions with more female rural work and fewer large land holdings. Divorce rate was higher where economic indicators were better (high income and schooling, better HDI-income), in more urbanized areas, and where there was a higher proportion of single-resident households. Single-resident households were more common in micro-regions with better HDI-income, more large land holdings, less urbanized areas, and less female rural work.

Multivariate analysis of the first-level variables (Table 4) shows an inverse association between schooling and male and female suicide rates. Rates were higher in micro-regions with a higher divorce rate. Male rates were higher where there were proportionally more traditional Protestants. Micro-regions with more single-resident households had lower suicide rates among women and also among men, but without reaching statistical significance $(p=0.06)$. No associations were found with population density or fertility rate.
Table 5 shows the results of the multivariate analysis of farm crops. Crude analysis of microregions with rice farming showed lower suicide rates. Soybeans, wheat, and corn crops were associated with high female suicide rates. After controlling for the effects of first-level factors, no significant associations were found between farm crops and either male or female suicide rates. However, rice crop showed a trend towards lower male suicide rates $(\mathrm{p}=0.06)$.

\section{Discussion}

This study focused on the relationships between social, agricultural, and economic indicators and high suicide rates in Rio Grande do Sul. Multivariate analysis highlighted the protective effect of schooling, which has been identified as a protective factor for various health problems, including mental health issues among farmers, such as minor psychiatric disorders, psychiatric hospitalizations, alcoholism, and use of psychi- 
Pearson correlation coefficients between socioeconomic variables, farm crops, and standardized suicide rates.

\begin{tabular}{|c|c|c|c|}
\hline \multirow[b]{2}{*}{ Independent variables } & \multicolumn{3}{|c|}{ Correlation coefficients ( $p$ valor) } \\
\hline & Male & Female & Total \\
\hline \multicolumn{4}{|l|}{ Socioeconomic and cultural } \\
\hline$\%$ Heads of family with income $>5$ minimum wage (1991) & $-0.32(0.06)$ & $-0.32(0.06)$ & $-0.36(0.03)$ \\
\hline$\%$ Schooling $\geq 8$ years $(\geq 15$ years age) $(1996)$ & $-0.43(0.01)$ & $-0.43(0.009)$ & $-0.49(0.003)$ \\
\hline HDI-Income (1991) & $-0.22(0.22)$ & $-0.48(0.003)$ & $-0.32(0.06)$ \\
\hline$\%$ Rural property $\geq 100$ ha (1996) & $-0.26(0.13)$ & $-0.48(0.003)$ & $-0.36(0.03)$ \\
\hline \% Urbanization rate (1996) & $-0.29(0.09)$ & $-0.53(0.001)$ & $-0.41(0.02)$ \\
\hline \% Women in rural workface (1996) & $0.35(0.04)$ & $0.54(0.001)$ & $0.44(0.008)$ \\
\hline Divorce rate $(1995)$ * & $0.01(0.93)$ & $-0.16(0.35)$ & $-0.06(0.74)$ \\
\hline$\%$ single-resident households (1991) & $-0.27(0.12)$ & $-0.70(<0.001)$ & $-0.43(0.01)$ \\
\hline \multicolumn{4}{|l|}{ Religion } \\
\hline \% Catholic (1991) & $-0.05(0.79)$ & $0.31(0.07)$ & $0.08(0.65)$ \\
\hline$\%$ Protestant (total) (1991) & $0.39(0.02)$ & $0.15(0.39)$ & $0.34(0.046)$ \\
\hline \% Traditional Protestant (1991) & $0.39(0.02)$ & $0.12(0.51)$ & $0.34(0.048)$ \\
\hline \% Pentecostal Protestant (1991) & $0.09(0.59)$ & $0.15(0.38)$ & $0.09(0.62)$ \\
\hline \multicolumn{4}{|l|}{ Principal farm crops (1996) (area cultivated/total area in 100ha) } \\
\hline Tobacco & $0.27(0.11)$ & $0.18(0.32)$ & $0.28(0.10)$ \\
\hline Rice & $-0.41(0.01)$ & $-0.53(0.001)$ & $-0.50(0.002)$ \\
\hline Soybeans & $0.09(0.61)$ & $0.38(0.03)$ & $0.17(0.34)$ \\
\hline Corn & $0.13(0.46)$ & $0.53(0.001)$ & $0.26(0.13)$ \\
\hline Wheat & $0.11(0.54)$ & $0.35(0.04)$ & $0.18(0.31)$ \\
\hline Beans & $0.004(0.98)$ & $0.28(0.10)$ & $0.08(0.65)$ \\
\hline Onions & $-0.24(0.17)$ & $-0.25(0.15)$ & $-0.26(0.13)$ \\
\hline Potatoes & $0.18(0.30)$ & $0.07(0.71)$ & $0.18(0.31)$ \\
\hline Tomatoes & $0.06(0.73)$ & $0.12(0.48)$ & $0.09(0.60)$ \\
\hline Apples & $0.16(0.36)$ & $0.00(1.00)$ & $0.16(0.35)$ \\
\hline Grapes & $-0.07(0.68)$ & $-0.01(0.95)$ & $-0.05(0.77)$ \\
\hline Peaches & $-0.16(0.37)$ & $-0.13(0.48)$ & $-0.15(0.39)$ \\
\hline
\end{tabular}

Divorce rate $=($ number of divorced + legally separated $) /$ population $\geq 15$ years $\times 1,000$.

atric medication 20. These results are consistent with those of international studies that also found inverse associations between education and suicide 4,20,21. In Canada, a nationwide study on farm workers showed a clear protective effect of schooling against suicide risk 21 .

Various studies have identified associations between poverty and increased risk of suicide $4,5,7,22,23$. In the crude analysis, income variables were inversely associated with suicide rates. However, this effect disappears after adjusting for other factors. A study in Campinas, São Paulo State, also showed no association between suicide rates and socioeconomic status 24 . It's possible that schooling may have more explanatory power for suicide, and when included with other economic indicators in the same equation, it may have done disappear their effect.

WHO has identified divorced, separated, and widowed individuals and those living alone among the groups most vulnerable to suicide risk 21 . In the current study, divorce rate was directly associated with suicide rates, especially in men. More than a century ago, Durkheim identified marriage as protective against suicide, principally in men 1 . Higher rates of divorce and legal separation and lower marriage rates have often been identified as indicators of social fragmentation and associated with increased suicide 2,3,20,21,22,25,26,27.

Another variable related to family structure is the percentage of individuals living alone. Several researchers have considered living alone as an indicator of isolation or social fragmentation $3,5,21,22$. Contrary to expectations, the current study found an inverse association between the proportion of single-resident households and female suicide rates (among men, this inverse association reached borderline statistical significance). Seeking to understand these results bet- 
Correlation matrix between economic, demographic, and socio-cultural variables (Pearson Correlation R).

\begin{tabular}{|c|c|c|c|c|c|c|c|c|c|}
\hline Variables & $\mathrm{X} 1$ & $\mathrm{X} 2$ & $\mathrm{X} 3$ & $\mathrm{X} 4$ & $\times 5$ & X6 & X7 & $\mathrm{x} 8$ & X9 \\
\hline X1-Income & 1.00 & 0.80 * & 0.73 * & 0.008 & -0.11 & 0.62 * & -0.13 & 0.11 & 0.53 * \\
\hline X2- Schooling & & 1.00 & $0.52^{\star *}$ & $0.32^{\star * *}$ & $-0.40 \#$ & 0.77 * & -0.16 & $0.32^{\star * *}$ & 0.59 * \\
\hline X3- HDI-Income & & & 1.00 & 0.13 & $-0.32^{\star \star \star}$ & 0.64 * & 0.01 & $0.35 \#$ & $0.33 \#$ \\
\hline X4- Large land holdings & & & & 1.00 & $-0.88 *$ & 0.56 * & $-0.50 * *$ & $0.75^{*}$ & 0.22 \\
\hline X5- Women in rural workforce & & & & & 1.00 & -0.67 * & $0.48^{* *}$ & $-0.80 *$ & -0.25 \\
\hline X6- Urbanization rate & & & & & & 1.00 & -0.18 & 0.66 * & 0.69 * \\
\hline X7- Traditional protestant & & & & & & & 1.00 & -0.18 & -0.06 \\
\hline X8- Single-resident households & & & & & & & & 1.00 & $0.35 \#$ \\
\hline X9- Divorce rate & & & & & & & & & 1.00 \\
\hline
\end{tabular}

$\mathrm{X} 1$ [High income $=\%$ heads of households with income $>5$ times the minimum wage]; $X 2$ [High schooling $=\%$ Population $\geq / 15$ years of age with $\geq 8$ years schooling]; X3 [Human Development Index-Income (HDI-income) = mean for municipalities in the micro-region]; $X 4$ [Large land holdings $=\%$ rural property $\geq$ 100 hectares]; X5 [Women in rural workforce $=\%$ women occupied in rural work]; X6 [Urbanization rate = \% urban population/total population]; X7 [Traditional protestants $=\%$ Lutherans, Baptists, Methodists, or Presbyterians]; X8 [Single-resident households = \% households in the micro-region with only one resident]; X9 [Divorce rate $=$ (number of divorced + legally separated/population $\geq 15$ years) $\times 1,000]$.

* $\mathrm{p} \leq 0.001$;

** $p \leq 0.01$;

*** $p<0.10$;

$\# p \leq 0.05$.

Table 4

Multivariate analysis: linear regression coefficients, crude and adjusted, confidence intervals (Cl), and $\mathrm{p}$ values.

Outcome: standardized suicide rates, male and female.

\begin{tabular}{|c|c|c|c|c|}
\hline \multirow[b]{2}{*}{ Socioeconomic variables } & \multicolumn{2}{|c|}{ Male } & \multicolumn{2}{|c|}{ Female } \\
\hline & Crude analysis $(\mathrm{Cl})$ & Adjusted analysis $(\mathrm{Cl})$ & Crude analysis $(\mathrm{Cl})$ & Adjusted analysis $(\mathrm{Cl})$ \\
\hline 1) High income & $-0.68(-1.38 ; 0.03)^{\star \star}$ & $0.06(-1.72 ; 1.85)$ & $-0.22(-0.45 ; 0.01)^{* \star}$ & $0.08(0.42 ; 0.58)$ \\
\hline 2) Schooling & $-0.66(-1.15 ;-0.17)^{\star \star \star *}$ & $-0.95(-1.50 ;-0.41) \#$ & $-0.22(-0.37 ;-0.06)^{* * *}$ & $-0.19(-0.35 ;-0.03) \# \#$ \\
\hline 3) HDI-Income & $-0.46(-1.19 ; 0.28)$ & $0.16(-0.60 ; 0.92)$ & $-0.33(-0.55 ;-0.12) * * *$ & $-0.13(-0.32 ; 0.06)$ \\
\hline 4) Large land holdings & $-0.08(-0.18 ; 0.02)$ & $0.11(-0.04 ; 0.26)$ & $-0.05(-0.08 ;-0.02)^{* * *}$ & $0.01(-0.06 ; 0.05)$ \\
\hline 5) Female rural workforce & 0.55 (0.02;1.08) \#\# & $-0.04(-1.51 ; 1.42)$ & $0.28(0.12 ; 0.43) \#$ & $-0.14(-0.35 ; 0.07)$ \\
\hline 6) Urbanization rate & $-0.16(-0.35 ; 0.03)$ & $0.03(-0.43 ; 0.48)$ & $-0.10(-0.15 ;-0.04) \#$ & $0.04(-0.08 ; 0.16)$ \\
\hline 7) Divorce rate & $0.22(-5.11 ; 5.55)$ & $7.14(1.75 ; 12.53)^{* \star \star}$ & $-0.80(-2.50 ; 0.91)$ & $1.74(0.30 ; 3.17) \# \#$ \\
\hline 8) Traditional protestants & $0.47(0.08 ; 0.87) \# \#$ & 0.52 (0.10;0.94) \#\# & $0.05(-0.09 ; 0.19)$ & $0.03(-0.09 ; 0.14)$ \\
\hline 9) Single-resident households & $-1.22(-2.78 ; 0.35)$ & $-2.01(-4.15 ; 0.13)^{\star *}$ & $-1.04(-1.41 ;-0.66) \#$ & $-1.27(-1.87 ;-0.66) \#$ \\
\hline 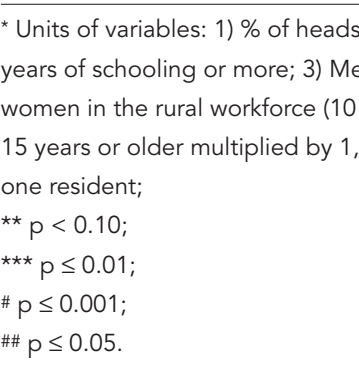 & $\begin{array}{l}\text { hold with income great } \\
\text { ncome for municipalitie } \\
\text { age or older); 6) urban } \\
\text { of traditional Protestan }\end{array}$ & $\begin{array}{l}\text { an } 5 \text { times the minimum w } \\
\text { e micro-region multiplied } \\
\text { ation as \% of total popula } \\
\text { population (Baptist, Meth }\end{array}$ & $\begin{array}{l}\text { \% of population } 15 \text { ye } \\
\text { 4) \% of rural holdings w } \\
\text { Individuals divorced c } \\
\text { Presbyterian, or Luthera }\end{array}$ & $\begin{array}{l}\text { older with } 8 \text { complete } \\
0 \text { hectares or more; } 5 \text { ) \% o } \\
\text { lly separated/population } \\
\% \text { of households with only }\end{array}$ \\
\hline
\end{tabular}


Table 5

Farm crops. Multivariate analysis: crude and adjust regression coefficients, $95 \%$ confidence intervals ( $\mathrm{Cl})$, and $\mathrm{p}$ value.

Outcome: standardized suicide rates, male and female.

\begin{tabular}{|c|c|c|c|c|c|c|c|c|}
\hline \multirow[b]{2}{*}{ Crops } & \multicolumn{3}{|c|}{ Male suicide } & \multicolumn{5}{|c|}{ Female suicide } \\
\hline & $\begin{array}{l}\text { Crude analysis } \\
\qquad(95 \% \mathrm{Cl})\end{array}$ & $p$ & $\begin{array}{c}\text { Adjusted analysis } \\
(95 \% \mathrm{Cl})\end{array}$ & $p$ & $\begin{array}{l}\text { Crude analysis } \\
\qquad(95 \% \mathrm{Cl})\end{array}$ & $p$ & $\begin{array}{c}\text { Adjusted analysis } \\
\qquad(95 \% \mathrm{Cl})\end{array}$ & $\mathrm{p}$ \\
\hline Tobacco & $0.12(-0.03 ; 0.28)$ & 0.11 & $0.04(-0.10 ; 0.19)$ & 0.55 & $0.03(-0.03 ; 0.08)$ & 0.32 & $0.03(0.01 ; 0.07)$ & 0.11 \\
\hline Rice & $-0.075(-0.13 ;-0.02)$ & 0.01 & $-0.06(-0.12 ; 0.003)$ & 0.06 & $-0.03(-0.05 ;-0.01)$ & 0.001 & $-0.05(-0.02 ; 0.01)$ & 0.60 \\
\hline Soybeans & $0.004(-0.01 ; 0.02)$ & 0.61 & $-0.01(-0.02 ; 0.007)$ & 0.29 & $0.005(0.001 ; 0.01)$ & 0.03 & $0.001(-0.004 ; 0.004)$ & 0.95 \\
\hline Wheat & $0.02(-0.04 ; 0.07)$ & 0.54 & $-0.03(-0.09 ; 0.03)$ & 0.36 & $0.02(0.001 ; 0.04)$ & 0.04 & $-0.001(-0.02 ; 0.01)$ & 0.90 \\
\hline Corn & $0.014(-0.02 ; 0.05)$ & 0.46 & $-0.02(-0.07 ; 0.04)$ & 0.51 & $0.02(0.008 ; 0.03)$ & 0.001 & $-0.001(-0.02 ; 0.01)$ & 0.88 \\
\hline Beans & $0.002(-0.15 ; 0.15)$ & 0.98 & $-0.06(-0.21 ; 0.09)$ & 0.40 & $0.04(-0.008 ; 0.09)$ & 0.10 & $-0.02(-0.06 ; 0.02)$ & 0.35 \\
\hline Onions & $-1.02(-2.50 ; 0.47)$ & 0.17 & $-0.61(-1.88 ; 0.65)$ & 0.33 & $-0.35(-0.83 ; 0.13)$ & 0.15 & $-0.13(-0.49 ; 0.21)$ & 0.43 \\
\hline Potatoes & $0.27(-0.25 ; 0.79)$ & 0.30 & $0.02(-0.47 ; 0.50)$ & 0.95 & $0.03(-0.14 ; 0.20)$ & 0.71 & $0.02(-0.12 ; 0.15)$ & 0.77 \\
\hline Tomatoes & $1.35(-6.62 ; 9.32)$ & 0.73 & $1.90(-6.68 ; 10.47)$ & 0.65 & $0.90(-1.67 ; 3.47)$ & 0.48 & $-0.46(-2.86 ; 1.94)$ & 0.70 \\
\hline Apples & $1.25(-1.48 ; 3.98)$ & 0.36 & $1.47(-0.93 ; 3.87)$ & 0.22 & $-0.001(-0.90 ; 0.90)$ & 1.00 & $-0.45(-1.10 ; 0.19)$ & 0.16 \\
\hline Grapes & $-0.05(-0.31 ; 0.20)$ & 0.68 & $0.02(-0.22 ; 0.27)$ & 0.84 & $0.003(-0.09 ; 0.08)$ & 0.95 & $-0.03(-0.091 ; 0.03)$ & 0.34 \\
\hline Peaches & $-1.00(-3.25 ; 1.24)$ & 0.37 & $-0.68(-2.69 ; 1.33)$ & 0.50 & $-0.26(-0.99 ; 0.47)$ & 0.48 & $-0.05(-0.62 ; 0.51)$ & 0.86 \\
\hline
\end{tabular}

* Male suicide adjusted for schooling, large land holdings, divorce rate, traditional Protestant religion, and single-resident households;

** Female suicide adjusted for schooling, HDI-Income, women in rural workforce, divorce rate, and single-resident households.

ter, it was observed that the micro-regions with the highest proportion of single-resident households included two types: those with predominantly large land holdings, with low population density (but where paradoxically the urbanization rate is high, since large land holdings employ very little labor) and industrialized and urbanized micro-regions, with higher mean income and schooling. More in-depth studies are necessary to understand this paradoxical finding.

Religion in general, regardless of type, has been inversely associated with suicide risk 28,29,30. The current study identified an association between male suicide and traditional Protestant religion, in agreement with Durkheim's classical result, showing higher suicide rates in predominantly Protestant regions (in the Brazilian case the traditional Protestant denominations). According to Durkheim, "Protestantism confers greater participation to individual thinking than Catholicism... because it has fewer common beliefs and practices", and suicide among Protestants "results from [Protestantism] being a less strongly integrated church than the Catholic church" 1 (p. 160). In the State of Rio Grande do Sul, traditional Protestantism is related to ethnic origin, especially Germanic. Qualitative analyses for the current study showed that among Lutheran parishes, the vast majority of worshippers were of German descent. Protestant religion may be a marker for Germanic ethnicity. Durkheim already indicated a strong proclivity to suicide among
Germans, both in Germany and abroad 1. However, the theme is controversial, since temporal trend analyses of suicide in Europe from 1985 to 1998 showed Germany with declining rates and in an intermediate position as compared to other European countries 31. Due to the lack of population data on ethnicity, it was not possible to formally test the associations between ethnicity and suicide in Brazil.

This study adopted the official definition of suicide ${ }^{9}$, i.e., death with the intention of self-destruction, the same criterion adopted by most authors $4,5,21,31$. Other studies have used a broader definition of suicide, including codes that did not define intended self-destruction 3,22,23,32, in addition to estimates derived from the supposition that some suicides were classified as accidents 33 . Some deaths from unknown causes may also be suicides due to ingestion of chemical substances. In Finland, where the quality of official health records is internationally renowned, it is estimated that indeterminate deaths lead to $10 \%$ underestimation of suicides 34 .

Thus, the possibilityofunder-recordingshould be considered, among other reasons because it is a type of death involving moral and religious issues. The present study's conclusions would only be affected by this problem if there were systematic differences in under-recording between the micro-regions (which appears unlikely).

Another methodological limitation of ecological studies is that results may not be con- 
firmed at the individual level (the ecological fallacy). Thus, the fact that a micro-region with a higher percentage of traditional Protestants or a lower proportion of single-resident households presents higher suicide rates does not necessarily mean that the suicide occurred among these individuals.

The current study's principal hypothesis was that factors related to farming activities, particularly pesticide use, were associated with the suicide rates. Some authors have associated the high rates observed in the State to the rural population and to agricultural activities 11,12,13, confirmed by the analysis of a 20-year temporal series in Rio Grande do Sul, where the highest rates were observed among farmers 10 . In addition, a study in the Serra Gaúcha region documented an $80 \%$ increase in the prevalence of minor psychiatric disorders among farmers as compared to the urban population ${ }^{16}$. It also found associations between mental health problems and farm production factors, especially pesticide poisoning 19 .

Suicide has been reported as a problem in rural populations in various countries, like China 35, India 36, Canada 21, Spain 37, United States 38, and Great Britain 39,40. In China, where the most common method was ingestion of pesticides, the rural suicide rate was three times than the urban, and five times greater in the most elderly group 35. In Canada, suicide rates among agricultural workers were associated with marketing of large amounts of oats and with seasonal agricultural work 21 . In Spain, the highest suicide rates were in the region with intensive agriculture and heavy pesticide use 37 .

In the current study, various factors linked to rural work were correlated with suicide, especially in women. Thus, suicide rates were higher in micro-regions with: a higher proportion of farm operations with less than 100 hectares, higher proportion of the population living in the rural area, and a higher proportion of women in the rural workforce. Three of the State's main crops (soybeans, wheat, and corn) showed a crude correlation with female suicide, while rice farming, which predominates in areas with large farming operations, was correlated with a reduction in suicide rates in both men and women. Still, the multivariate analysis did not show any consistent association between these agricultural variables and suicide rates.

Some studies on suicide in rural populations have shown associations to pesticide use $12,21,37$. Due to the limitations in the database of Agronomical Pesticide Prescriptions in terms of the amounts of pesticides used in agriculture, it was not possible to test this association. In addition, one of the hypotheses leading to the current study, that there could be a specific association between tobacco growing and suicide, was not confirmed by the data presented above. However, although the main tobacco-growing areas showed higher suicide rates, although the association was not statistically significant and the excess risk disappeared after adjusting for socioeconomic and cultural factors.

On the other hand, precarious socioeconomic conditions may be associated with inadequate pesticide handling, involving "less advanced" farming practices. Thus, inadequate pesticide use may be a mediator between low socioeconomic status and suicides. The lack of reliable data on pesticide use did not allow testing this hypothesis in the current study.

This study confirmed the severity of the suicide phenomenon in Rio Grande do Sul and showed correlations between suicide and social and economic factors. The results highlighted schooling as a protective factor against suicide, reinforcing the importance of social determination of suicides. Meanwhile, the authors recognize the need for more specific studies to verify other associations, like the effect of ethnicity or pesticide exposure. Understanding the relationships between rural work and suicides is a challenge that remains to be overcome. 


\section{Resumo}

As taxas de suicídio do Rio Grande do Sul são as mais elevadas do Brasil. Estudos anteriores sugeriram uma associação com atividades agrícolas, particularmente a fumicultura, onde o uso de agrotóxicos seria particularmente intenso. Um delineamento ecológico foi utilizado para identificar fatores associados ao suicídio, tendo as 35 microrregiões do Estado como unidades de análise. Coeficientes de mortalidade por suicídios, baseados no registro de óbitos, foram padronizados por idade, sendo suas associações com fatores sócioeconômicos culturais e agrícolas avaliadas por meio de regressão linear múltipla. As taxas de suicídio, para ambos os sexos, foram inferiores em microrregiões com escolaridade elevada, e superiores onde havia maior proporção de casamentos desfeitos. As taxas masculinas foram superiores nas microrregiões com mais evangélicos tradicionais e as femininas foram menores em microrregiões com maior proporção de domicílios com um morador. Na análise ajustada não foram evidenciadas associações entre suicídios e estrutura agrária ou culturas agrícolas. Estes resultados confirmam a importância de fatores sócio-econômicos na ocorrência do suicídio, mas não apóiam a hipótese de um papel específico das práticas agrícolas.

Coeficiente de Mortalidade; População Rural; Religião; Escolaridade; Suicídio

\section{References}

1. Durkheim E. O suicídio. São Paulo: Martin Claret; 2003

2. Makinen I. Are there social correlates to suicide? Soc Sci Med 1997; 44:1919-29.

3. Hawton K, Harriss L, Hodder K, Simkin S, Gunnell $D$. The influence of the economic and social environment on deliberate self-harm and suicide: an ecological and person-based study. Psychol Med 2001; 31:827-36.

4. Page A, Morrell S, Taylor R. Suicide differentials in Australian males and females by various measures of socio-economic status, 1994-98. Aust N Z J Public Health 2002; 26:318-24.

5. Qin P, Agerbo E, Mortensen PB. Suicide risk in relation to socioeconomic, demographic, psychiatric, and familial factors: a national register-based study of all suicides in Denmark, 1981-1997. Am J Psychiatry 2003; 160:765-72.

6. Stack S. Suicide: a 15-year review of the sociological literature. Part I: cultural and economic factors. Suicide Life Threat Behav 2000; 30:145-61.

\section{Contributors}

N. M. X. Faria designed the project, organized the database, conducted the statistical analysis, reviewed the literature, discussed the results, and drafted several versions of the article. C. G. Victora reviewed and approved the project, supported the organization of the database, supervised the statistical analysis, discussed the results, reviewed all the drafts of the article, and approved the final version. S. N. Meneghel participated in the project design, reviewed the literature, discussed the results, reviewed the initial draft, and approved the final version of the article. L. A. Carvalho designed the project, discussed the results, and reviewed and approved the final version. J. W. Falk participated in the project design, discussed the results, and reviewed and approved the final version.
7. World Health Organization. Preventing suicide - a resource for primary health care workers. Geneva: Department of Mental Health, World Health Organization; 2000

8. World Health Organization. Global percentage of deaths due to injury (1999). http://www.ops-oms. org/english/ad/dpc/nc/global-injury-slide.pps (accessed on 10/Jun/2004).

9. Núcleo de Informações sobre Saúde, Secretaria de Saúde e Meio Ambiente do Rio Grande do Sul. Estatísticas de saúde - mortalidade. Porto Alegre: Núcleo de Informações sobre Saúde, Secretaria de Saúde e Meio Ambiente do Rio Grande do Sul; 1995.

10. Meneghel S, Victora CG, Faria NMX, Carvalho LA, Falk JW. Características epidemiológicas do suicídio no Rio Grande do Sul. Rev Saúde Pública 2004; 38:804-10

11. Leal OF. Suicídio, honra e masculinidade na cultura gaúcha. Cadernos de Antropologia - UFRGS 1992; (6):7-21. 
13. Falk JW, Carvalho LA, Silva LR, Pinheiro S. Suicídio e doença mental em Venâncio Aires - RS: conseqüências do uso de agrotóxicos organofosforados? Porto Alegre: Comissão de Cidadania e Direitos Humanos, Assembléia Legislativa do Rio Grande do Sul; 1995.

14. Werlang R. Suicídio: uma análise causal das taxas de mortalidade-suicídio no Rio Grande do Sul. In: XLII Congresso da Sociedade Brasileira de Economia e Sociologia Rural. Cuiabá: Sociedade Brasileira de Economia e Sociologia Rural; 2004. p. 20.

15. Departamento de Informação e Informática do SUS/Fundação Nacional de Saúde/Centro Nacional de Epidemiologia. Sistema de informação sobre mortalidade, 1979-1998, dados de declaração de óbito. Brasília: Ministério da Saúde; 2000.

16. Ahmad OB, Boschi-Pinto C, Lopez AD, Murray CJ, Lozano R, Inoue M. Age standardization of rates: a new WHO standard. http://www3.who.int/whosis/discussion_papers/pdf/paper31.pdf (accessed on 27/Mar/2003).

17. Faria NMX, Facchini LA, Fassa AG, Tomasi E. Processo de produção rural e saúde na Serra Gaúcha: um estudo descritivo. Cad Saúde Pública 2000; 16:115-28.

18. Nicolella A, Ferreira E, Lessa C. Relatório de atendimento 2002. Porto Alegre: Centro de Informação Toxicológica do Rio Grande do Sul, Secretaria Estadual de Saúde; 2003.

19. Kirkwood BR. Essentials of medical statistics. London: Blackwell Scientific Publications; 1988.

20. Faria NM, Facchini LA, Fassa AG, Tomasi E. Estudo transversal sobre saúde mental de agricultores da Serra Gaúcha (Brasil). Rev Saúde Pública 1999; 33:391-400.

21. Agerbo E, Nordentoft M, Mortensen PB. Familial, psychiatric, and socioeconomic risk factors for suicide in young people: nested case-control study. BMJ 2002; 325:74.

22. Pickett W, King WD, Lees RE, Bienefeld M, Morrison HI, Brison RJ. Suicide mortality and pesticide use among Canadian farmers. Am J Ind Med 1998; 34:364-72.

23. Whitley E, Gunnell D, Dorling D, Smith GD. Ecological study of social fragmentation, poverty, and suicide. BMJ 1999; 319:1034-7.

24. Blakely TA, Collings SC, Atkinson J. Unemployment and suicide. Evidence for a causal association? J Epidemiol Community Health 2003; 57:594-600.

25. Marin-Leon L, Barros MB. Óbitos por suicídio: diferenças de gênero e nível socioeconômico. Rev Saúde Pública 2003; 37:357-63.

26. Gunnell D, Middleton N, Whitley E, Dorling D, Frankel S. Why are suicide rates rising in young men but falling in the elderly? A time-series analysis of trends in England and Wales 1950-1998. Soc Sci Med 2003; 57:595-611.
27. Aihara H, Iki M. Effects of socioeconomic factors on suicide from 1980 through 1999 in Osaka Prefecture, Japan. J Epidemiol 2002; 12:439-49.

28. Chuang HL, Huang WC. A reexamination of "sociological and economic theories of suicide: a comparison of the U.S.A. and Taiwan". Soc Sci Med 1996; 43:421-3.

29. Gunnell D, Eddleston M. Suicide by intentional ingestion of pesticides: a continuing tragedy in developing countries. Int J Epidemiol 2003; 32:902-9.

30. Clarke CS, Bannon FJ, Denihan A. Suicide and religiosity - Masaryk's theory revisited. Soc Psychiatry Psychiatr Epidemiol 2003; 38:502-6.

31. Neeleman J, Lewis G. Suicide, religion, and socioeconomic conditions. An ecological study in 26 countries, 1990. J Epidemiol Community Health 1999; 53:204-10.

32. Chishti P, Stone DH, Corcoran P, Williamson E, Petridou E. Suicide mortality in the European Union. Eur J Public Health 2003; 13:108-14.

33. Bartlett CJ, Gunnell D, Harrison G, Moore L. Neurotic symptoms, stress, or deprivation: which is most closely associated with incidence of suicide? An ecological study of English Health Authorities. Psychol Med 2002; 32:1131-6.

34. Cassorla RMS, Smeke ELM. Autodestruição humana. Cad Saúde Publica 1994; 10 Suppl 1:61-73.

35. Ohberg A, Lonnqvist J. Suicides hidden among undetermined deaths. Acta Psychiatr Scand 1998; 98:214-8.

36. Phillips MR, Li X, Zhang Y. Suicide rates in China, 1995-99. Lancet 2002; 359:835-40.

37. Aaron R, Joseph A, Abraham S, Muliyil J, George $\mathrm{K}$, Prasad J, et al. Suicides in young people in rural southern India. Lancet 2004; 363:1117-8.

38. Parron T, Hernández AF, Villanueva E. Increase risk of suicide with exposure to pesticides in an intensive agricultural area. A 12-year retrospective study. Forensic Sci Int 1996; 79:53-63.

39. Singh GK, Siahpush M. Increasing rural-urban gradients in US suicide mortality, 1970-1997. Am J Public Health 2002; 92:1161-7.

40. Middleton N, Gunnell D, Frankel S, Whitley E, Dorling D. Urban-rural differences in suicide trends in young adults: England and Wales, 1981-1998. Soc Sci Med 2003; 57:1183-94.

41. Booth N, Briscoe M, Powell R. Suicide in the farming community: methods used and contact with health services. Occup Environ Med 2000; 57:642-4.

Submitted on 26/Jan/2005

Final version resubmitted on 31/Aug/2005

Approved on 04/Oct/2005 